\title{
Internalization of art value of syarafal anam adults characters building
}

\section{Muhammad Nikman Naser, Budrianto}

\author{
IAIN Bengkulu, Bengkulu, Indonesia
}

nikmanmuhammad2015@gmail.com

Submitted : 18-04-2021, Revised : 26-04-2021, Accepted : 24-05-2021

\begin{abstract}
Teenagers always want to try new things, but there is a gap between their desires and the demands of society. The thinking of adolescents who are still unstable requires values that become their benchmarks for behaviour so that they become adolescents with character. The purpose of this research is to study and analyze the values contained in the syarafal anam culture which can later be transformed into the adolescent generation and applied in counselling guidance services. This research is an ethnographic study, the data analysis used is the composition analysis. The results of the study found that in syarafal cultural activities there are values of a religious character, creativity, fondness of reading and friendship.
\end{abstract}

Keywords: Value Internalization; Youth Character; Syarafal Anam

\section{Introduction}

Individual personality traits are generally formed through the educational process, both at school, at home and in social settings. Character building can be obtained from the sociocultural environment, not only the learning process at school (Hermino \& Redjeki, 2020; Liu et al., 2020; Omeri, 2015). In the social environment, individuals can easily understand the characters of the people around them. Character education is intended for all people to have a better quality of life. The character of adolescents is also a problem that often occurs.

The thinking of adolescents who are still unstable also affects the character that is in them. Adolescence is a time of wandering life with irrational behaviour and unstable thinking (Blakemore, 2018; Schneiderman et al., 2020). The turmoil of an adolescent soul makes individuals always want to do anything, but not all desires can be fulfilled. This is caused by community problems which become the benchmark for adolescents in their actions. Values and life habits shape the behaviour carried out by individuals (Sari et al., 2020; Sari \& Bulantika, 2019). Values and traditions that exist in a culture can be internalized in an individual's life.

One of the traditions in Bengkulu society is syarafal anam. Syarafal anam is cultural performance art of the Lembak people who live in the midst of the Lembak community in Bengkulu City, this Art Video contains praises to Allah SWT and Prophet Muhammad SAW accompanied by tambourine musical instruments and Malay dances (Haryani et al., 2013; Tarobin, 2015). Individuals who observe this art expect to have the ability to learn to understand every beat and chanted verse. Syarafal anam make individuals have good emotional control and a high artistic spirit so that they can correctly sing the music of this game.

A complete individual character is also listed in the independence standards of students in counselling guidance. Individuals must have an awareness of social responsibility, selfdevelopment and maturity in peer relationships. For this to be achieved, a good character is needed for individuals, so that individuals have good character, values that can shape their character are needed. The values of individual culture and social norms are internalized through personal norms and indirectly or directly influence the formation of individual characters (Díaz 
et al., 2017; S. H. Kim \& Seock, 2019). The influence of tradition in shaping individual character makes it important to study the values that exist in that tradition. Therefore, this study examines the values that exist in syarafal anam which can be internalized in the formation of individual characters.

\section{Method}

This research is an ethnographic study, which will examine the values in the art of syarafal anam to shape the character of adolescents. This study was conducted in the setting of the Bengkulu soft community. Data collection was carried out by observation and interviews with cultural observers and adolescents who observe the art of syarafal anam. The data analysis used was composed analysis, by organizing each element that was triangulated.

\section{Results and Discussion}

Based on the results of interviews and observations carried out in two groups of Syarafal anam in the city of Bengkulu, it is known that there are several stages in understanding and implementing this art, starting from being able to read the Al-Qur'an, learning beats on redap musical instruments, and maintaining cohesiveness in groups. Table 1 describes the activity of syarafal anam and the values in the formation of the characters contained in it.

Table 1. Proses Aktivitas Pelaksanaan Syarafal Anam

\begin{tabular}{|c|c|c|}
\hline No. & Syarafal Anam Activity & Interpretation \\
\hline 1. & $\begin{array}{l}\text { Beat practice } \\
\text { Hadrah/Napa/Bedikir Siang } \\
\text { (Pukulan PumPak/PakPak } \\
\text { PumPak) }\end{array}$ & $\begin{array}{l}\text { The process of orientation and adaptation in the context of } \\
\text { Syarafal Anam's learning, by introducing basic beats as a } \\
\text { rhythm and rhyme regulator. The cognitive aspects of the } \\
\text { individual can be seen in the process of observation and the } \\
\text { curiosity of the activists. The dimension of character education } \\
\text { is formed through thought or literacy. When referring to the } \\
\text { perspective of counselling, this activity helps individuals } \\
\text { develop themselves, attitudes and learning habits. The } \\
\text { character values contained are curiosity and love to read. }\end{array}$ \\
\hline 2. & $\begin{array}{l}\text { Practice understanding and } \\
\text { chanting of poetry or song } \\
\text { (Ahlol, Talap Naba, Sallu } \\
\text { Mani Salam, Wa Ulpi, Ya } \\
\text { Nabi, Ya Rahman) }\end{array}$ & $\begin{array}{l}\text { Continuous thought process as an independent learning process. } \\
\text { The aspects of individual cognition are increasingly formed } \\
\text { because in this stage there is an independent task by repeating } \\
\text { the understanding obtained from the teacher outside of learning } \\
\text { and tested in each exercise. In this aspect, it is still related to the } \\
\text { learning aspect, namely literacy and curiosity. }\end{array}$ \\
\hline 3. & $\begin{array}{l}\text { A balance between beat } \\
\text { and rhyme }\end{array}$ & $\begin{array}{l}\text { Process of taste by upholding the integration of morals, a sense } \\
\text { of art and culture. Affective or emotional aspects are balanced } \\
\text { by integrating all series of Syarafal Anam learning holistically. } \\
\text { The character values reflected in this activity are creative } \\
\text { characters that require individuals to understand beats and } \\
\text { rhymes. }\end{array}$ \\
\hline 4 & $\begin{array}{l}\text { Solidarity or emotional in } \\
\text { performance or appearance }\end{array}$ & $\begin{array}{l}\text { The values of cooperation and solidarity within the framework } \\
\text { of kinship are formed as a manifestation of the implementation } \\
\text { of cooperation. Mutual hopelessness, asi and asu as well as } \\
\text { covering up the shortcomings of members if there is a deliberate }\end{array}$ \\
\hline
\end{tabular}


or unintentional mistake as a collaborative principle. The substance of the $\mathrm{BK}$ is so that individuals can develop understanding and social skills or human relations. The values contained in this activity are friendly.

The first activity in syarafal anam is the practice of the beat of Hadrah / Napa / Bedikir Siang (PakPak PumPak) which is interpreted as the basic foundation in this art. The theoretical basis for art can be seen from a variety of beat patterns, situations and conditions. There needs to be intensive learning so that the results of this first activity can be optimal. By studying and exploring traditions, individuals will have a true religious character and a curiosity that encourages a person to continue to learn about the values that drive their actions (Birenbaum et al., 2019; B. Kim \& Kim, 2018). In more detail, the value system in this stage is (1) stimulates cognitive thinking to think rationally, (2) provides an in-depth understanding of Arabic which is the language of the Koran, (3) a form of glorifying Allah SWT, (4) a form of glorifying Rasulullah SAW, (5) forging spiritual skills that can become skills in educating future generations. The values contained in this exercise are the values that shape the character of religiosity and curiosity. These values can shape religious and insightful individuals.

The second part of the process is a form of content mastery that adolescents must-have. The independent and guided learning system will be the theoretical basis which is a follow-up to the first part of the process. Learning motivation will be formed at this stage because every week the meeting will be reflected as a learning evaluation. The main principles of learning in the 21 st century prioritize Instructional Should be Student-Centered, the development of learning should use an individual-centred learning approach (Hosnan, 2014; Nichols, 2015) Individuals are placed as learning subjects, who actively develop their interests and potential, showing the values that shape literacy and curiosity. One of the forms of the ability to like reading is by having a curiosity about one thing, the individual tries to construct his knowledge and skills, according to his capacity and level of thinking development (Holschuh, 2019; Oktavianti et al., 2017).

The third part as a form of emotional management is a process of feeling by upholding moral integration and creativity to understand every beat and verse. Judging from the performance of the stage, syarafal anam is a kind of percussion music performance. The tambourines were beaten with a fast, loud, insistent frequency with a predominantly loud rhythm, overlaid by loud voices reciting praises to the apostle with a heroic spirit. This situation if the wasp uncontrolled and lack the creativity in understanding each beat will make the show unattractive. This forms a creative character, one of the important things in understanding the rhythm of music is to have high creativity (Firdhani, 2021; Sudjono \& Kusumastuti, 2017; Van Der Schyff et al., 2018) .

This fourth part is a form of direct learning application, which is reflected in the values of cooperation, solidarity within the framework of kinship is formed as a form of cooperation. The attitude of mutual despair, asi and asu as well as covering the shortcomings of members in escapes and mistakes that accompany the performers of syarafal anam art, especially the youth generation Values can form a friendly character, by covering up each other's shortcomings and 
cooperation between groups. Friendship makes the activities carried out conducive and makes solidarity higher in the organization (Blatterer, 2020).

Values in a culture must be considered in the implementation of guidance and counselling services. The internalization of values in a habit in a certain culture can form a strong character for individuals so that they can behave by applicable norms (Sari et al., 2018, 2020; Sari \& Bulantika, 2019). Judging from the process of Syarafal anam's activity itself, in its personal aspect, a personality that upholds the concept of religiosity will be formed as seen from the process of understanding religion in concept and substance. Furthermore, in the social aspect, sensitivity, cooperation and solidarity will be formed which is reflected in their group activities. More than that, the formation of learning motivation is implemented from the encouragement from within and an environment that demands mastering teaching on an ongoing basis.

\section{Conclusions and Suggestions}

The art of Syarafal anam culture forms an order of attitudes and behaviour that are packaged through a traditional art frame, which contains values that can shape individual characters such as values of religiosity, love of reading, creativity, curiosity and friendship. These values can be internalized in counselling services to alleviate personal-social problems and learn so that individuals will have good character in various aspects of life. Suggestions for further researchers to construct syarafal stages as a strategy in providing group guidance services. For the counsellor, the values in the syarafal anam can be used to build the character of the counselee.

\section{References}

Birenbaum, M., Alhija, F. N.-A., Shilton, H., Kimron, H., Rosanski, R., \& Shahor, N. (2019). A further look at the five-dimensional curiosity construct. Personality and Individual Differences, 149, 57-65.

Blakemore, S.-J. (2018). Avoiding social risk in adolescence. Current Directions in Psychological Science, 27(2), 116-122.

Blatterer, H. (2020). Friendship and solidarity. European Journal of Social Theory, 1368431020982499.

Díaz, A., Gómez, M., \& Molina, A. (2017). A comparison of online and offline consumer behaviour: An empirical study on a cinema shopping context. Journal of Retailing and Consumer Services, 38, 44-50.

Firdhani, A. M. (2021). Peningkatan Kemampuan Musikal Peserta Didik Melalui Aktivitas Musik Kreatif. Indonesian Journal Of Performing Arts Education, 1(1).

Haryani, O., Huda, S., \& Topan, A. (2013). Kesenian Sarafal Anam Dan Nilai-Nilai Yang Terkandung di dalamnya pada Masyarakat Lembak dalam Adat Istiadat (Studi Kasus di Kelurahan Dusun Besar Kecamatan Singaran Pati Kota Bengkulu). Universitas Bengkulu.

Hermino, A., \& Redjeki, D. S. S. (2020). The Importance of Character-Based Health Education in School to Improve Quality of Health Living in Indonesia. Asian Social Science, 16(10).

Holschuh, J. P. (2019). College reading and studying: The complexity of academic literacy task demands. Journal of Adolescent \& Adult Literacy, 62(6), 599-604.

Hosnan, M. (2014). Pendekatan saintifik dan kontekstual dalam pembelajaran abad 21: Kunci sukses implementasi kurikulum 2013.

Kim, B., \& Kim, S. S. (2018). Hierarchical value map of religious tourists visiting the 
Vatican City/Rome. Tourism Geographies.

Kim, S. H., \& Seock, Y.-K. (2019). The roles of values and social norm on personal norms and pro-environmentally friendly apparel product purchasing behavior: The mediating role of personal norms. Journal of Retailing and Consumer Services, 51, 83-90.

Liu, L., Xu, L., Xiao, X., Liu, L., \& Li, Y. (2020). Positive influence of peers' interpersonal character on children's interpersonal character: The moderating role of children's and peers' social status. Journal of Adolescence, 79, 157-172.

Nichols, J. R. (2015). Four Essential Rules of 21st Century Learning.

Oktavianti, I., Zuliana, E., \& Ratnasari, Y. (2017). Menggagas kajian kearifan budaya lokal di sekolah dasar melalui gerakan literasi sekolah. Kudus: Universitas Muria Kudus.

Omeri, N. (2015). Pentingnya pendidikan karakter dalam dunia pendidikan. Manajer Pendidikan, 9(3).

Sari, P., \& Bulantika, S. Z. (2019). Konseling indigenous berbasis tata nilai budaya lampung "piil pesenggiri" dalam pembentukan. 9(2), 190-199.

Sari, P., Suryawati, C. T., \& Bulantika, S. Z. (2020). Internalisasi Nilai-nilai Piil Pesenggiri untuk Mencegah Perilaku Bullying Siswa SMK. 6(1), 1-7.

Sari, P., Triyono, T., \& Mappiare, A. (2018). Panduan Pertimbangan Nilai Ajaran Nengah Nyappur Etnis Lampung untuk Mereduksi Perilaku Bullying Siswa SMK. Jurnal Pendidikan: Teori, Penelitian, Dan Pengembangan, 3(8), 1095-1099.

Schneiderman, J. U., Kennedy, A. K., Granger, T. A., \& Negriff, S. (2020). Predictors and correlates of unstable housing experiences among a child welfare-involved sample. Journal of Public Child Welfare, 14(2), 192-208.

Sudjono, E. T. K., \& Kusumastuti, E. (2017). Proses Pembelajaran Gerak dan Lagu yang Kreatif Berdasarkan Kurikulum 2013 di TK Miryam Semarang. Jurnal Seni Tari, 6(2).

Tarobin, M. (2015). Seni "Sarafal Anam” di Bengkulu: Makna, Fungsi dan Pelestarian. Jurnal Bimas Islam, 8(2), 265-296.

Van Der Schyff, D., Schiavio, A., Walton, A., Velardo, V., \& Chemero, A. (2018). Musical creativity and the embodied mind: Exploring the possibilities of $4 \mathrm{E}$ cognition and dynamical systems theory. Music \& Science, 1, 2059204318792319. 
